\title{
High frequency of enterotoxin encoding genes of Staphylococcus aureus isolated from food and clinical samples
}

\author{
Fakhri Haghi ${ }^{1,2}$, Habib Zeighami $^{1 *}$ (D, Zeynab Hajiloo ${ }^{3}$, Neda Torabi $^{3}$ and Safoura Derakhshan ${ }^{4}$
}

\begin{abstract}
Background: Staphylococcus aureus is recognized as an important cause of food poisoning related to the consumption of raw, undercooked, or mishandled foods worldwide.

Methods: A total of 90 individual meat samples and 200 clinical specimens were collected and investigated the frequency of $S$. aureus and classical enterotoxin genes. The samples were cultured on Baird-Parker and Mannitol salt agar and subjected for confirmatory biochemical tests and molecular detection of femA, sea, seb, sec, sed, and see genes.

Results: A total of 31 (34.5\%) meat samples and 81 (40.5\%) clinical specimens were positive for the presence of S. aureus. These isolates were detected with slightly higher frequency in clinical specimens than food samples $(P>0.05)$.

Furthermore, the frequency of $S$. aureus in raw meat (23.4\%) was higher than that in cooked meat samples (11.1\%) $(P<$ 0.05). Staphylococcal enterotoxin (SE) genes were identified in 18 (58.1\%) of 31 meat isolates and 42 (51.8\%) of 81 clinical isolates. The frequency of SE genes (except see) in meat isolates was slightly higher than that in clinical isolates $(P>0.05)$. We found sea and see genes with higher frequency than others in both meat and clinical samples. Furthermore, 55.5\% of meat isolates and $38.1 \%$ of clinical isolates possessed more than one se gene.

Conclusion: Detection of enterotoxigenic S. aureus in clinical and raw meat samples shows a probable risk for public health. Therefore, intensive and continuous monitoring of potentially pathogenic S. aureus is strongly recommended in order to evaluate the human health risk arising from food consumption.
\end{abstract}

Keywords: Staphylococcus aureus, Classical enterotoxins, Clinical samples, Meat, PCR

\section{Background}

Staphylococcus aureus is one of the most common causes of bacterial food poisoning worldwide, causing an estimated 241,148 cases and 6 deaths per year in the USA [1-3]. According to a report of Iranian centers of public health in the central province of Iran, the prevalence of staphylococcal food poisoning in this region is considerable [4]. Staphylococcal food poisoning (SFP) is related to the consumption of foods containing sufficient

\footnotetext{
* Correspondence: zeighami@zums.ac.ir

1 Department of Microbiology, School of Medicine, Zanjan University of Medical Sciences, Zanjan, Iran

Full list of author information is available at the end of the article
}

amounts of one or more preformed enterotoxins [5-8]. The high incidence of staphylococcal food poisoning is due to the insufficient pasteurization/decontamination of originally contaminated product source or its contamination during preparation and handling by individuals who are carriers of the organism [9].

Because the skin and mucous membranes of animals are considered as the reservoirs for S. aureus, this microorganism has enough potential to exist and transmit to or contaminate and spoil animal products such as milk and meat [10]. Foods that have been frequently incriminated in staphylococcal intoxication include raw retail meat and meat products, poultry and egg products, milk 
and dairy products, salads, bakery products, particularly cream-filled pastries and cakes, and sandwich fillings [11]. As S. aureus is frequently isolated in raw milk, it is responsible for an increase in milk somatic cell count and a decrease in milk's nutritional composition and productivity [12].

S. aureus produces a wide variety of toxins belonging to the fascinating family of superantigens including staphylococcal enterotoxins (SEs; SEA-SEE, SEG-SEI, and SER-SET) and staphylococcal enterotoxin-like (SEls) toxins, which their emetic properties remain unconfirmed (SEIK-SEIQ and SEIU-SEIX). SEs and SEls are single-chain proteins with size range from 22 to $29 \mathrm{KDa}$ and encoded by accessory genetic elements including plasmids, prophages, pathogenicity islands, and genomic island $\mathrm{vSa}$, or by genes located next to the staphylococcal cassette chromosome (SCC) [11, 13-15]. The amount of SE required for the establishment of typical symptoms of food poisoning including nausea, vomiting, emesis, stomach cramps, and diarrhea is very low and approximately ranging from $20 \mathrm{ng}$ to $1 \mu \mathrm{g}$ [16-18]. Among SEs, SEA is the most common cause of staphylococcal food poisoning worldwide, but the involvement of other classical SEs has been also demonstrated [11]. Due to the stability of SEs in denaturing conditions such as heat and low $\mathrm{pH}$, these toxins are not completely destroyed by mild cooking or digestion of food in the stomach $[19,20]$.

Although enterotoxigenic staphylococci are thermally destroyed, the cooked meat products may contain SEs because these toxins are thermostable and cannot be destroyed by heat processing. This fact represents a serious hazard to healthy consumer when ready-to-eat meat products are processed [21]. Therefore, it is essential to detect SE-producing staphylococci and gather information about other microbial risk factors and hazards associated with raw and pre-processed meat products. Risk assessment and microbial monitoring will continue to play important role in the quality assurance of meat products [21].

The detection of S. aureus and SEs in food is difficult. Methods currently used for the detection of SEs in food are enzyme-linked immunosorbent assay (ELISA), reversed passive latex agglutination (SET-RPLA), and polymerase chain reaction (PCR) technique [19].

Several studies have investigated staphylococcal enterotoxins in food samples such as raw milk and dairy products, but there are few such studies on meat samples [10]. Furthermore, there is a lack of information on the occurrence of enterotoxin producing $S$. aureus in meat and clinical samples in our region. So, we aimed in the present study to investigate the presence and the frequency of $S$. aureus and classical SE genes in meat and clinical samples in Zanjan, Iran.

\section{Methods}

\section{Patients and sampling}

This prospective study was approved by the Research Ethics Committee of Zanjan University of Medical Sciences (IR.ZUMS.REC.1394.69) and informed written consent was obtained from patients. The study population was comprised of all hospitalized patients with clinical presentations such as urinary tract infection, bacteremia, meningitis, synovitis, and wound infections admitted to four major university hospitals in Zanjan, Iran, from March to June 2015. Patients were enrolled in the study if they had not taken any antimicrobial agent in the week preceding sampling. Clinical specimens including blood (47), synovial fluid (22), urine (29), CSF (33), and wound (69) were collected from patients. One sample from each patient was collected and transported to the laboratory of Medical Microbiology in a cool box within $1 \mathrm{~h}$.

Due to the distribution of meat retail outlets and restaurants in Zanjan, the cluster sampling method was used. At first, Zanjan was divided into 4 geographical regions based on the abundance of meat retail outlets and restaurants. Then, a total of 19 restaurants and 25 meat retail outlets were selected. One to three samples were collected from each meat retail outlet and restaurant.

From March to June 2015, a total of 90 individual meat samples including raw beef (23), raw lamb (22), and cocked meat (45) samples were collected from meat retail outlets and restaurants. Meat samples were packed into a clean polyethylene bag then marked and transported to the laboratory of Microbiology in a cool box for analysis within $1 \mathrm{~h}$.

\section{Reference strains}

Reference strains of S. aureus ATCC 13565 (SEA), S. aureus ATCC 14458 (SEB), S. aureus ATCC 19095 (SEC), S. aureus ATCC 23235 (SED), and S. aureus ATCC 27664 (SEE) were used as positive controls in this study.

\section{Isolation and identification of $S$. aureus}

Twenty-five grams of meat samples was homogenized for $90 \mathrm{~s}$ in a stomacher (Heidolph, Schwabach, Germany) with $225 \mathrm{ml}$ of peptone water (PW) containing $6.5 \% \mathrm{NaCl}$ and then incubated at $37^{\circ} \mathrm{C}$ for $24 \mathrm{~h}$. After primary enrichment, a loopful (without shaking the flask) from each of the enriched homogenates was streaked onto Baird-Parker agar (MERCK, Darmstadt, Germany) supplemented with 5\% egg yolk and tellurite and incubated under aerobic conditions at $37{ }^{\circ} \mathrm{C}$ for $24 \mathrm{~h}$. Colonies with typical gray-black appearance surrounded by a clear zone were enumerated as coagulase-positive staphylococci and sub-cultured onto Mannitol salt agar. Clinical specimens were also cultured onto Brain Heart Infusion agar and Mannitol salt agar 
(MERCK, Darmstadt, Germany) [22, 23]. The isolates were identified as $S$. aureus by further biochemical characterization using Gram stain, catalase, coagulase, oxidase, lipase, DNase, and PCR targeting the S. aureus-specific femA gene (S. aureus species specific).

\section{Genomic DNA extraction}

A colony of $S$. aureus (one colony per sample) was picked from nutrient agar and inoculated into $5 \mathrm{ml}$ of LB (Luria Bertani Broth, Merck) until the exponential phase with 2 McFarland turbidity with shaking at $120 \mathrm{rpm}$ at $37^{\circ} \mathrm{C}$. Extraction of genomic DNA was performed according to the protocol provided with the Qiagen Mini Amp kit.

\section{Detection of sea-see in S. aureus isolates by PCR}

The presence of staphylococcal enterotoxin genes sea, seb, $s e c$, sed, and see was assessed using the primers listed in Table 1. Single PCR was performed using DreamTaq PCR Master Mix (Thermo Fisher Scientific), which contains Taq polymerase, dNTPs, $\mathrm{MgCl}_{2}$, and the appropriate buffer. Each PCR tube contained $25 \mu \mathrm{l}$ reaction mixture composed of $12.5 \mu \mathrm{l}$ of the master mix, $2.5 \mu \mathrm{l}$ of each forward and reverse primer solution (in a final concentration of $200 \mathrm{nM}$ ), $2 \mu \mathrm{l}$ of DNA with a concentration of $400 \mathrm{ng}$, and nuclease-free water to complete the final volume. PCR was performed using the Gene Atlas 322 system (ASTEC) with the same cycling conditions for sea-see genes. Amplification involved an initial denaturation at $94^{\circ} \mathrm{C}, 5 \mathrm{~min}$ followed by 30 cycles of denaturation $\left(94^{\circ} \mathrm{C}, 1.5 \mathrm{~min}\right)$, annealing $\left(55^{\circ} \mathrm{C}, 1.5 \mathrm{~min}\right)$, and extension $\left(72{ }^{\circ} \mathrm{C}, 1.5 \mathrm{~min}\right)$, with a final extension step (72 ${ }^{\circ} \mathrm{C}, 8 \mathrm{~min}$ ). The amplified DNA was separated by submarine gel electrophoresis on $1.5 \%$ agarose, stained with ethidium bromide, and visualized under UV transillumination.

\section{Statistical analysis}

The data were analyzed with SSPS version 17.0 software (SPSS, Inc., Chicago, IL). The chi-square test was used to determine the statistical significance of the data. A $P$ value of $<0.05$ was considered significant.

\section{Results}

Frequency of $S$. aureus in clinical samples and meat

Of the total number of patients (200), 38 (19\%) were 15-30 years, 72 (36\%) were $30-45$ years, 58 (29\%) were $45-60$ years, and $32(16 \%)$ were $>60$ years. The sex distribution was $55 \%$ male and $45 \%$ female.

Overall, 81 (40.5\%) S. aureus isolates were identified in the 200 clinical samples: 20 (10\%) isolates of blood, 17 (8.5\%) isolates of CSF, 5 (2.5\%) isolates of synovial fluid, $29(14.5 \%)$ isolates of wound, and $10(5 \%)$ isolates of urine samples.

A total of 90 individual meat samples were studied for the presence of $S$. aureus. A conventional cultural method based on the appearance of gray-black colonies surrounded by a clear zone on Baird-Parker agar plates was detected coagulase-positive staphylococci in 43 (47.8\%) out of the 90 samples. However, the biochemical tests and molecular analysis of $f e m A$ in coagulasepositive staphylococci indicated that $34.5 \%$ (31/90) of samples were positive for $S$. aureus: 12 (13.4\%) isolates from raw lamb, 9 (10\%) isolates from raw beef, and 10 (11.1\%) isolates from cooked meat samples (Table 2).

\section{Distribution of enterotoxin genes in S. aureus isolates}

Overall, 58.1\% (18/31) of meat isolates were positive for the presence of at least one or more SE genes: 10 isolates (32.3\%) from lamb and 8 isolates (25.8\%) from beef samples. The frequency of each SE gene in S. aureus isolates is shown in Table 3. Comparison of SE gene frequency among beef and lamb isolates showed a different distribution of these genes. The most prevalent SE gene among beef and lamb isolates was sea (38.7\%), followed by see $(22.6 \%)$, sec $(16.1 \%)$, and seb (12.9\%). SE genes were not found in strains isolated from cooked meat samples.

Among 81 clinical isolates, $42(51.8 \%)$ isolates carried at least one or more enterotoxin genes. The frequency of sea, $s e b, s e c$, sed, and see genes in clinical isolates was $28.4 \%$, $11.1 \%, 9.9 \%, 3.7 \%$, and $27.1 \%$, respectively (Table 3 ).

Table 1 Primers used in this study

\begin{tabular}{|c|c|c|c|}
\hline Target & Primer sequence $\left(5^{\prime} \rightarrow 3^{\prime}\right)$ & Amplicon size (bp) & References \\
\hline femA & $\begin{array}{l}\text { AAAAAAGCACATAACAAGCG } \\
\text { GATAAAGAAGAAACCAGCAG }\end{array}$ & 132 & [24] \\
\hline sea & $\begin{array}{l}\text { CCTTTGGAAACGGTTAAAACG } \\
\text { TCTGAACCTTCCCATCAAAAAC }\end{array}$ & 127 & [25] \\
\hline seb & $\begin{array}{l}\text { TCGCATCAAACTGACAAACG } \\
\text { GCAGGTACTCTATAAGTGCC }\end{array}$ & 477 & {$[25]$} \\
\hline $\sec$ & $\begin{array}{l}\text { CTCAAGAACTAGACATAAAAGCTAGG } \\
\text { TCAAAATCGGATTAACATTATCC }\end{array}$ & 271 & [25] \\
\hline sed & $\begin{array}{l}\text { CTAGTTTGGTAATATCTCCTTTAAACG } \\
\text { TTAATGCTATATCTTATAGGGTAAACATC }\end{array}$ & 319 & [25] \\
\hline see & $\begin{array}{l}\text { CAGTACCTATAGATAAAGTTAAAACAAGC } \\
\text { TAACTTACCGTGGACCCTTC }\end{array}$ & 178 & [25] \\
\hline
\end{tabular}


Table 2 Frequency of $S$. aureus in meat and clinical samples

\begin{tabular}{llll}
\hline Samples (no.) & No. (\%) of samples containing S. aureus & No. & \\
\cline { 2 - 4 } & Positive samples & 12 & (\%) \\
\hline Raw lamb (22) & A2, A3, A5, A7, A8, A9, A10, A14, A16, A18, A19, A21 & 9 & 13.4 \\
Raw beef (23) & B1, B2, B3, B6, B8, B9, B10, B12, B13 & 10 & 10 \\
Cooked meat (45) & C5, C13, C16, C24, C26, C32, C34, C35, C39, C45 & 20 & 11.1 \\
Blood (47) & D1, D5, D8-D10, D15, D17, D20, D21, D24, D25-D32, D39, D42 & 17 & 10 \\
CSF (33) & E3, E8, E11, E13, E14- E18, E21, E23-E27, E30, E33 & 5 & 8.5 \\
Synovial fluid (22) & F6, F12, F17, F20, F22 & 29 & 2.5 \\
Wound (69) & G2, G7-G10, G13, G18, G20-G26, G31, G37-G41, G45, G49-G52, & 14.5 \\
Urine (29) & G55, G57, G59, G61 & 10 & $\mathbf{1 1 2}$ \\
Total (290) & H3-H5, H11, H14, H16, H19, H21, H25, H28 & 5 \\
\hline
\end{tabular}

The presence of multiple SE genes with different combinations was found among isolates. Of 18 meat isolates and 42 clinical isolates harboring enterotoxin genes, 10 (55.5\%) and 16 (38.1\%) isolates, respectively, had two or more SE genes simultaneously. The number of SEs per isolate and their specific combinations are shown in Table 4. The frequent combination of SE genes in meat isolates was sea+see (16.7\%), followed by sea+seb+see (11.1\%). One isolate (5.5\%) of lamb samples carried sea+ $s e b+s e c+$ see simultaneously. Many of the clinical isolates (61.9\%) had only one SE gene (30.9\% sea, $26.2 \%$ see, $2.4 \% \mathrm{sec}$, and $2.4 \% \mathrm{sed}$ ). The frequent combination of SE genes among clinical isolates was sea+seb+see $(9.5 \%)$ and sea + seb $(7.1 \%)$, respectively.

\section{Discussion}

Staphylococcus aureus is the most common foodborne pathogen and represents a major public health problem in developing countries [1]. Several studies have shown an increasing prevalence of $S$. aureus in food samples such as raw milk and dairy products, raw meat, and meat products $[10,11,19]$. In our study, a total of 81 (40.5\%) clinical specimens and 31 (34.5\%) meat samples were positive for the presence of $S$. aureus. These isolates were detected with slightly higher frequency in clinical specimens than food samples $(P>0.05)$. Furthermore, the frequency of $S$. aureus in raw meat (23.4\%) was higher than that in cooked meat samples (11.1\%) $(P<0.05)$. Only a few reports on the frequency of $S$. aureus in clinical and meat samples from Iran have been published. According to the previous reports from Iran, 3.7-15.6\% of the meat samples [26] and $20.8 \%$ of clinical specimens [27] were positive for the presence of this pathogen. Raw meat contamination with $S$. aureus has been reported $24 \%$ in Italy yielding positive cultures [28]. According to Moon et al. [29] and Aydin et al. [30], the frequency of $S$. aureus in meat products was $36 \%$ and $13.8 \%$, respectively.

This variation in $S$. aureus frequency may be due to differences in the geographical region, reservoir in the various countries, sample type, number of samples, seasons of sampling, post-harvest practices, and hygienic standards applied during the handling, transport, and storage of products, as well as the methods used for isolation and identification of this bacterium. Meat contamination may occur at various stages in preparation including transport, butchering, and cut-up in the

Table 3 Frequency of SE genes among S. aureus isolates

\begin{tabular}{|c|c|c|c|c|c|c|c|c|c|c|}
\hline \multirow[t]{2}{*}{ Enterotoxin } & \multicolumn{4}{|c|}{ No. (\%) of meat isolates carrying SE genes $(n=18)$} & \multicolumn{6}{|c|}{ No. $(\%)$ of clinical isolates carrying SE genes $(n=42)$} \\
\hline & $\begin{array}{l}\text { Raw lamb } \\
\text { isolates } \\
(n=12)\end{array}$ & $\begin{array}{l}\text { Raw beef } \\
\text { isolates } \\
(n=9)\end{array}$ & $\begin{array}{l}\text { Cooked meat } \\
\text { isolates } \\
(n=10)\end{array}$ & $\begin{array}{l}\text { Total } \\
(n=31)\end{array}$ & $\begin{array}{l}\text { Blood } \\
\text { isolates } \\
(n=20)\end{array}$ & $\begin{array}{l}\text { CSF } \\
\text { isolates } \\
(n=17)\end{array}$ & $\begin{array}{l}\text { Synovial fluid } \\
\text { isolates }(n=5)\end{array}$ & $\begin{array}{l}\text { Wound } \\
\text { isolates } \\
(n=29)\end{array}$ & $\begin{array}{l}\text { Urine } \\
\text { isolates } \\
(n=10)\end{array}$ & $\begin{array}{l}\text { Total } \\
(n=81)\end{array}$ \\
\hline sea & $5(16.1)$ & $7(22.6)$ & 0 & $12(38.7)$ & $7(8.6)$ & $5(6.2)$ & $2(2.4)$ & $5(6.2)$ & $4(4.9)$ & $23(28.4)$ \\
\hline seb & $3(9.7)$ & $1(3.2)$ & 0 & $4(12.9)$ & $2(2.4)$ & $1(1.2)$ & $1(1.2)$ & $3(3.7)$ & $2(2.4)$ & $9(11.1)$ \\
\hline sec & $4(12.9)$ & $1(3.2)$ & 0 & $5(16.1)$ & $3(3.7)$ & $2(2.4)$ & $1(1.2)$ & $2(2.4)$ & 0 & $8(9.9)$ \\
\hline sed & $1(3.2)$ & $1(3.2)$ & 0 & $2(6.4)$ & $1(1.2)$ & $1(1.2)$ & $1(1.2)$ & 0 & 0 & $3(3.7)$ \\
\hline see & $3(9.7)$ & $4(12.9)$ & 0 & $7(22.6)$ & $6(7.4)$ & 7 (8.6) & $2(2.4)$ & $4(4.9)$ & $3(3.7)$ & $22(27.1)$ \\
\hline
\end{tabular}


Table 4 Specific SE combinations among the 26 S. aureus isolates (10 meat and 16 clinical isolates) carrying more than one SE genes

\begin{tabular}{llll}
\hline SE combinations & \multicolumn{3}{l}{$\begin{array}{l}\text { No. (\%) of isolates carrying } \\
\text { SE genes combinations }\end{array}$} \\
\cline { 2 - 4 } & $\begin{array}{l}\text { Meat isolates } \\
\text { carrying SE } \\
\text { genes }(\boldsymbol{n}=18)\end{array}$ & $\begin{array}{l}\text { Clinical isolates } \\
\text { carrying SE } \\
\text { genes }(\boldsymbol{n}=42)\end{array}$ & $\begin{array}{l}\text { Total } \\
(\boldsymbol{n}=60)\end{array}$ \\
\hline sea+sed & $1(5.5)$ & - & $1(1.6)$ \\
sea+seb & $1(5.5)$ & $3(7.1)$ & $4(6.6)$ \\
seb+sec & - & $1(2.4)$ & $1(1.6)$ \\
sec+see & - & $2(4.7)$ & $2(2.4)$ \\
sea+sec & - & $1(2.4)$ & $1(1.6)$ \\
sea+see & $3(16.7)$ & $2(4.7)$ & $5(6.2)$ \\
sec+sed & $1(5.5)$ & $1(2.4)$ & $2(2.4)$ \\
sea+seb+see & $2(11.1)$ & $4(9.5)$ & $6(10)$ \\
sea+sec+see & $1(5.5)$ & - & $1(1.6)$ \\
sea+seb+sec & - & $1(2.4)$ & $1(1.6)$ \\
sea+sec+sed+see & - & $1(2.4)$ & $1(1.6)$ \\
sea+seb+sec+see & $1(5.5)$ & - & $1(1.6)$ \\
Total & $10(55.5)$ & $16(38.1)$ & $26(43.3)$ \\
\hline
\end{tabular}

kitchen, and the importance of chopping boards as a source of contamination has been reported [31-35].

SE genes were identified in 18 (58.1\%) of 31 meat isolates and $42(51.8 \%)$ of 81 clinical isolates. The frequency of enterotoxigenic $S$. aureus in meat samples was higher than that in clinical specimens $(P>0.05)$. According to results, the frequency of SE genes (except see) in meat isolates was slightly higher than that in clinical isolates $(P>0.05)$. We found sea and see genes with higher frequency than others in both meat and clinical samples. Similar to our results, SEA is considered to be the most common cause of food poisoning in Korea and Japan [36]. Furthermore, several studies reported that enterotoxin genes sea and sed were the most common in staphylococci isolated from food $[20,32,37]$. However, a lower incidence of sed (6.4\%) was detected in our study. In contrast to our results, seb was a prevalent gene in food poisoning cases reported in Taiwan and Japan and sec was a major SE gene in isolates from bulk milk in Switzerland and in Korea [36].

It has been known that the se/sel genes are carried on mobile genetic elements and most of them contain several se/sel genes simultaneously. SE genes are located on plasmids (sed and sej), phages (sea, see, and sep), and pathogenicity islands on chromosomes (seb, sec, seg, seh, sei, sek, sel, sem, sen, seo, and seq) [30, 38]. In our study, 55.5\% of meat isolates and $38.1 \%$ of clinical isolates possessed more than one se gene. Seven se genotypes were observed in meat isolates, and the most commonly detected were sea+ see $(16.7 \%)$ and sea+seb+see (11.1\%). Nine se genotypes were also detected in clinical specimens, and the most frequent combinations were sea+seb+see $(9.5 \%)$ and sea+ seb (7.1\%), respectively.

\section{Conclusion}

The presence of enterotoxin producing $S$. aureus in clinical and raw meat samples represents a potential health risk. Therefore, intensive and continuous monitoring of potentially pathogenic $S$. aureus is strongly recommended in order to evaluate the human health risk arising from food consumption.

\section{Abbreviations \\ SFP: Staphylococcal food poisoning; SE: Staphylococcal enterotoxin; SCC: Staphylococcal cassette chromosome; ELISA: Enzyme-linked immunosorbent assay; PCR: Polymerase chain reaction}

\section{Acknowledgements}

The authors are grateful to the Zanjan University of Medical Sciences for supporting this study.

\section{Authors' contributions}

$\mathrm{FH}$ : project development, manuscript writing, and data analysis; $\mathrm{HZ}$ : project development, data management, data analysis, and manuscript writing; $\mathrm{ZH}$ and NT: data collection and project development; SD: project development. All authors read and approved the final manuscript.

\section{Funding}

This work as an MSc thesis in Medical Microbiology was supported by the Zanjan University of Medical Sciences (A-12-392-12, ZUMS.REC.1394.69).

\section{Availability of data and materials}

The datasets will not be available on a publically available website, but it may be possible to provide access to anonymized data.

\section{Declarations}

Ethics approval and consent to participate

The study was based on clinical samples collected from Zanjan University hospitals as Ethics no. ZUMS.REC.1394.69.

Consent for publication

Not applicable

Competing interests

The authors declare that they have no competing interests.

\section{Author details}

${ }^{1}$ Department of Microbiology, School of Medicine, Zanjan University of Medical Sciences, Zanjan, Iran. ${ }^{2}$ Student Research Committee, Zanjan University of Medical Sciences, Zanjan, Iran. ${ }^{3}$ Department of Microbiology, Zanjan Branch, Islamic Azad University, Zanjan, Iran. ${ }^{4}$ Department of Microbiology, Faculty of Medicine, Kurdistan University of Medical Sciences, Sanandaj, Iran.

Received: 16 September 2019 Accepted: 22 April 2021

Published online: 09 June 2021

\section{References}

1. Fetsch A, Contzen M, Hartelt K, Kleiser A, Maassen S, Rau J, et al. Staphylococcus aureus food-poisoning outbreak associated with the consumption of ice-cream. Int J Food Microbiol. 2014;187:1-6. https://doi. org/10.1016/j.ijfoodmicro.2014.06.017.

2. Tiemersma EW, Bronzwaer SL, Lyytikainen O, Degener JE, Schrijnemakers $P$, Bruinsma N, et al. Methicillin-resistant Staphylococcus aureus in Europe, 1999-2002. Emerg Infect Dis. 2004;10(9):1627-34. https://doi.org/10.3201/ eid1009.040069.

3. Johler S, Weder D, Bridy C, Huquenin MC, Robert L, Hummerjohann J, et al. Outbreak of staphylococcal food poisoning among children and staff at a 
Swiss boarding school due to soft cheese made from raw milk. J Dairy Sci. 2015:98(5):2944-8. https://doi.org/10.3168/jds.2014-9123.

4. Fooladvand S, Sarmadian H, Habibi D, van Belkum A, Ghaznavi-Rad E. High prevalence of methicillin resistant and enterotoxin gene-positive Staphylococcus aureus among nasally colonized food handlers in central Iran. Eur J Clin Microbiol Infect Dis. 2019;38(1):87-92. https://doi.org/10.1 007/s10096-018-3398-0.

5. Hennekinne J-A, Ostyn A, Guillier F, Herbin S, Prufer A-L, Dragacci S. How should staphylococcal food poisoning outbreaks be characterized? Toxins. 2010;2(8):2106-16. https://doi.org/10.3390/toxins2082106.

6. Letertre C, Perelle S, Dilasser F, Fach P. Identification of a new putative enterotoxin SEU encoded by the egc cluster of Staphylococcus aureus. J Appl Microbiol. 2003;95(1):38-43. https://doi.org/10.1046/j.1365-2672.2003.01957.x.

7. Akineden O, Hassan AA, Schneider E, Usleber E. Enterotoxigenic properties of Staphylococcus aureus isolated from goats' milk cheese. Int J Food Microbiol. 2008;124(2):211-6. https://doi.org/10.1016/j. ijfoodmicro.2008.03.027.

8. Tkáčiková L, Tesfaye A, Mikula I. Detection of the genes for Staphylococcus aureus enterotoxins by PCR. Acta Vet Brno. 2003;72(4):627-30. https://doi. org/10.2754/avb200372040627.

9. Pinchuk IV, Beswick EJ, Reyes VE. Staphylococcal enterotoxins. Toxins (Basel). 2010;2(8):2177-97. https://doi.org/10.3390/toxins2082177.

10. Mashouf RY, Hosseini SM, Mousavi SM, Arabestani MR. Prevalence of enterotoxin genes and antibacterial susceptibility pattern of Staphylococcus aureus strains isolated from animal originated foods in West of Iran. Oman Med J. 2015;30(4):283-90. https://doi.org/10.5001/omj.2015.56.

11. Argudín MÁ, Mendoza MC, Rodicio MR. Food poisoning and Staphylococcus aureus enterotoxins. Toxins. 2010;2(7):1751-73. https://doi. org/10.3390/toxins2071751.

12. Moura EO, AHNR, Macêdo CS, Urbano SA, Novaes LP, Lima Júnior DM Enterotoxin-encoding genes in Staphylococcus aureus from buffalo milk. Brazilian J Vet Res. 2019;39(8):5.

13. Podkowik M, Park J, Seo K, Bystroń J, Bania J. Enterotoxigenic potential of coagulase-negative staphylococci. Int J Food Microbiol. 2013;163(1):34-40. https://doi.org/10.1016/j.ijfoodmicro.2013.02.005.

14. Hu DL, Nakane A. Mechanisms of staphylococcal enterotoxin-induced emesis. Eur J Pharmacol. 2014;722:95-107. https://doi.org/10.1016/j.ejphar.2 013.08.050.

15. Otto M. Staphylococcus aureus toxins. Curr Opin Microbiol. 2014;17:32-7. https://doi.org/10.1016/.jmib.2013.11.004.

16. Hennekinne JA, De Buyser ML, Dragacci S. Staphylococcus aureus and its food poisoning toxins: characterization and outbreak investigation. FEMS Microbiol Rev. 2012;36(4):815-36. https://doi.org/10.1111/j.1574-6976.2011. 00311.x.

17. Ortega E, Abriouel H, Lucas R, Gálvez A. Multiple roles of Staphylococcus aureus enterotoxins: pathogenicity, superantigenic activity, and correlation to antibiotic resistance. Toxins. 2010;2(8):2117-31. https://doi.org/10.3390/ toxins 2082117.

18. Tranter HS. Foodborne staphylococcal illness. Lancet. 1990;336(8722):1044-6. https://doi.org/10.1016/0140-6736(90)92500-H.

19. Wu X, Su Y-C. Growth of Staphylococcus aureus and enterotoxin production in pre-cooked tuna meat. Food Control. 2014;42:63-70. https://doi.org/10.1 016/j.foodcont.2014.01.039.

20. Ertas N, Gonulalan Z, Yildirim Y, Kum E. Detection of Staphylococcus aureus enterotoxins in sheep cheese and dairy desserts by multiplex PCR technique. Int J Food Microbiol. 2010;142(1-2):74-7. https://doi.org/10.1016/j. ijfoodmicro.2010.06.002.

21. Rodríguez A, Gordillo R, Andrade MJ, Córdoba JJ, Rodríguez M. Development of an efficient real-time PCR assay to quantify enterotoxinproducing staphylococci in meat products. Food Control. 2016;60:302-8. https://doi.org/10.1016/j.foodcont.2015.07.040.

22. Hait J, Tallent S, Melka D, Keys C, Bennett R. Prevalence of enterotoxins and toxin gene profiles of Staphylococcus aureus isolates recovered from a bakery involved in a second staphylococcal food poisoning occurrence. J Appl Microbiol. 2014;117(3):866-75. https://doi.org/10.1111/jam.12571.

23. Khaledian S, Pajohi-Alamoti M, Mahmoodi P. Molecular characterization of methicillin-resistant enterotoxin-producing Staphylococcus aureus isolated from Samosa and Falafel in Iran. Int J Enteric Pathogens. 2020;8(1):19-24. https://doi.org/10.34172/ijep.2020.05.

24. da Silva ER, do Carmo LS, da Silva N. Detection of the enterotoxins $A, B$, and $C$ genes in Staphylococcus aureus from goat and bovine mastitis in
Brazilian dairy herds. Vet Microbiol. 2005;106(1-2):103-7. https://doi.org/10.1 016/j.vetmic.2004.12.005.

25. Omoe K, Hu DL, Takahashi-Omoe H, Nakane A, Shinagawa K. Comprehensive analysis of classical and newly described staphylococcal superantigenic toxin genes in Staphylococcus aureus isolates. FEMS Microbiol Lett. 2005;246(2):1918. https://doi.org/10.1016/j.femsle.2005.04.007.

26. Sarrafzadeh Zargar M, Hosseini Doust R, Mohebati Mobarez A. Staphylococcus aureus enterotoxin A gene isolated from raw red meat and poultry in Tehran, Iran. Int J Enteric Pathog. 2014;2(4):4.

27. Salari Sharif A, Sattari M, Moradi M, Shahrokhabad R. Detection of Staphylococcus aureus entrotoxin genes A \& B in clinical samples of the patients referring to the medical centers of Kerman and Rafsanjan cities by PCR technique. Rums J. 2012;11(2):128-36.

28. Pesavento G, Ducci B, Comodo N, Nostro AL. Antimicrobial resistance profile of Staphylococcus aureus isolated from raw meat: a research for methicillin resistant Staphylococcus aureus (MRSA). Food Control. 2007;18(3):196-200. https://doi.org/10.1016/j.foodcont.2005.09.013.

29. Moon JS, Lee AR, Jaw SH, Kang HM, Joo YS, Park YH, et al. Comparison of antibiogram, staphylococcal enterotoxin productivity, and coagulase genotypes among Staphylococcus aureus isolated from animal and vegetable sources in Korea. J Food Prot. 2007;70(11):2541-8. https://doi. org/10.4315/0362-028X-70.11.2541.

30. Aydin A, Sudagidan M, Muratoglu K. Prevalence of staphylococcal enterotoxins, toxin genes and genetic-relatedness of foodborne Staphylococcus aureus strains isolated in the Marmara Region of Turkey. Int J Food Microbiol. 2011;148(2):99-106. https://doi.org/10.1016/j.jffoodmicro.2 011.05.007.

31. Ho J, O'Donoghue MM, Boost MV. Occupational exposure to raw meat: a newly-recognized risk factor for Staphylococcus aureus nasal colonization amongst food handlers. Int J Hyg Environ Health. 2014;217(2-3):347-53. https://doi.org/10.1016/j.jigheh.2013.07.009.

32. Alibayov B, Zdenkova K, Sykorova H, Demnerova K. Molecular analysis of Staphylococcus aureus pathogenicity islands (SaPI) and their superantigens combination of food samples. J Microbiol Methods. 2014;107:197-204. https://doi.org/10.1016/j.mimet.2014.10.014.

33. Morandi S, Brasca M, Lodi R, Cremonesi P, Castiglioni B. Detection of classical enterotoxins and identification of enterotoxin genes in Staphylococcus aureus from milk and dairy products. Vet Microbiol. 2007; 124(1-2):66-72. https://doi.org/10.1016/j.vetmic.2007.03.014.

34. Guven K, Mutlu MB, Gulbandilar A, Cakir P. Occurrence and characterization of Staphylococcus aureus isolated from meat and dairy products consumed in Turkey. J Food Saf. 2010;30(1):196-212.

35. Normanno G, La Salandra G, Dambrosio A, Quaglia NC, Corrente M, Parisi A, et al. Occurrence, characterization and antimicrobial resistance of enterotoxigenic Staphylococcus aureus isolated from meat and dairy products. Int J Food Microbiol. 2007;115(3):290-6. https://doi.org/10.1016/j. ijfoodmicro.2006.10.049.

36. Hwang SY, Kim SH, Jang EJ, Kwon NH, Park YK, Koo HC, et al. Novel multiplex PCR for the detection of the Staphylococcus aureus superantigen and its application to raw meat isolates in Korea. Int J Food Microbiol. 2007; 117(1):99-105. https://doi.org/10.1016/j.ijfoodmicro.2007.02.013.

37. Aragon-Alegro LC, Konta EM, Suzuki K, Silva MG, Júnior AF, Rall R, et al. Occurrence of coagulase-positive Staphylococcus in various food products commercialized in Botucatu, SP, Brazil and detection of toxins from food and isolated strains. Food Control. 2007;18(6):630-4. https://doi.org/10.1016/ j.foodcont.2006.02.010.

38. Lawrynowicz-Paciorek M, Kochman M, Piekarska K, Grochowska A, Windyga B. The distribution of enterotoxin and enterotoxin-like genes in Staphylococcus aureus strains isolated from nasal carriers and food samples. Int J Food Microbiol. 2007;117(3):319-23. https://doi.org/10.1016/j. iifoodmicro.2007.03.009.

\section{Publisher's Note}

Springer Nature remains neutral with regard to jurisdictional claims in published maps and institutional affiliations. 